line. Vessels used for timber-floating are also permitted to deviate from the frontier and also vessels in distress. It is forbidden without special permission to conduct conversations or to fraternize in other ways with persons on the other side of the frontier. On rivers which form part of the frontier, vessels may only ply during the hours of daylight. Norwegian citizens are permitted to fish in rivers and lakes which form part of the frontier as long as they keep on the Norwegian side of the frontier-line, but it is forbidden to use explosives, poison, or anaesthetic materials to kill or injure the fish.

\title{
THE INTER-AMERICAN TREATY OF RECIPROCAL ASSISTANCE, RIO DE JANEIRO, 1947
}

[Based on Inter-American conference for the maintenance of continental peace and security... Report of the delegation of the United States of America. Washington, U.S. Government Printing Office, 1948. (Department of State Publication 3016.)]

The Treaty of Rio de Janeiro (for the mutual defence of the Americas), which was signed on 2 September 1947, begins with a condemnation of war by the high contracting parties and a pledge not to resort to force in any manner inconsistent with the Charter of the United Nations or the treaty itself. The contracting parties undertake to endeavour to settle such controversies as may arise between them before referring them to the General Assembly or the Security Council of the United Nations.

The vital Article III registers agreement that an armed attack by any State against an American State shall be considered as an attack against all the American States. Each contracting party undertakes to assist in meeting the attack. On the request of the State or States attacked, and pending the decision of the "Organ of Consultation", each contracting party may determine the measures which it should itself adopt to fulfil this obligation.

The interest of the treaty to readers of the Polar Record lies in Article IV, which states:

The region to which this Treaty refers is bounded as follows: beginning at the North Pole; thence due south to a point 74 degrees north latitude, 10 degrees west longitude; thence by a rhumb line to a point $\mathbf{4 7}$ degrees 30 minutes north latitude, 50 degrees west longitude; thence by a rhumb line to a point 35 degrees north latitude, 60 degrees west longitude; thence due south to a point in 20 degrees north latitude; thence by a rhumb line to a point 5 degrees north latitude, 24 degrees west longitude; thence due south to the South Pole; thence due north to a point 30 degrees south latitude, 90 degrees west longitude; thence by a rhumb line to a point on the Equator at 97 degrees west longitude; thence by a rhumb line to a point 15 degrees north latitude, 120 degrees west longitude; thence by a rhumb line to a point 50 degrees north latitude, 170 degrees east longitude; thence due north to a point in 54 degrees north latitude; thence by a rhumb line to a point 65 degrees 30 minutes north latitude, 168 degrees 58 minutes 5 seconds west longitude; thence due north to the North Pole.

These boundaries completely enclose the American continent, including Alaska, the Aleutian Islands, Canada and Greenland. Canada is not a member of the Pan-American Union, a signatory of the Act of Chapultepec (which 
this treaty implements), or a signatory of this treaty. Greenland is Danish territory, and the United States has negotiated with Denmark a separate agreement concerning its defence, ${ }^{1}$ to which she ascribes great importance. It will also be noted that the boundaries extend southwards to the South Pole and include the whole of the Falkland Islands Dependencies except a small sector between longs. $20^{\circ} \mathrm{W}$. and $24^{\circ} \mathrm{W}$. The area thus includes the British territory whose sovereignty is disputed by Argentina and Chile. ${ }^{2}$

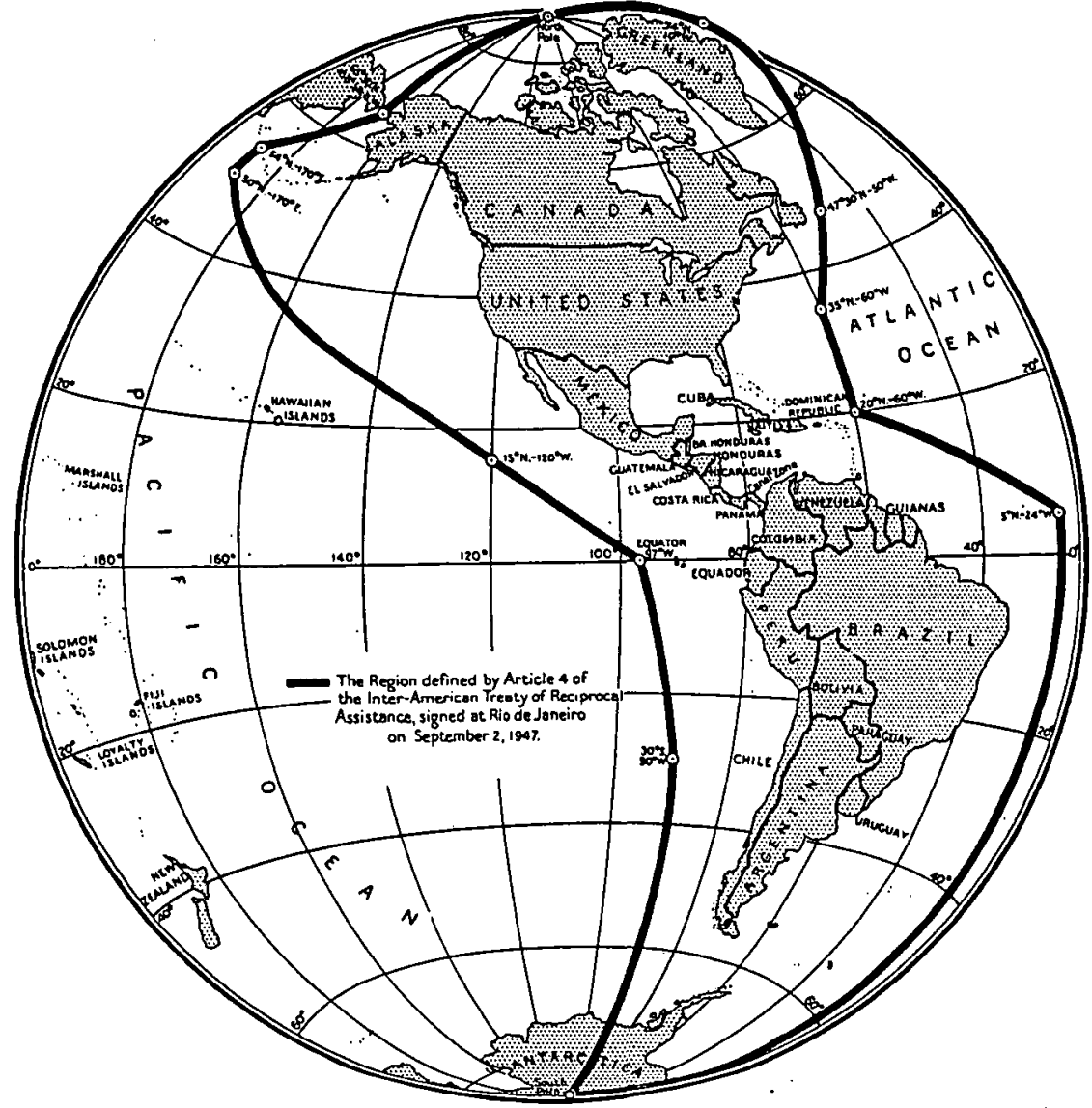

The region defined by Article IV of the Inter-American Treaty of Reciprocal Assistance.

The Treaty of Rio de Janeiro, of which Great Britain is not a signatory, also provides (Article VI) that if the "inviolability or the integrity of the territory or the sovereignty or political independence of any American State should be affected by an aggression which is not an armed attack" or by any situation that might endanger the peace of America, the Organ of Consultation shall meet immediately to agree on the measures to be taken. In addition to other acts which the Organ of Consultation may characterize as aggression, the treaty specifies (Article IX $b$ ): "Invasion, by the armed forces of a State, of the territory of an American State, through the trespassing of boundaries

\footnotetext{
1 See p. 407-12.
}

2 See p. 4.13-18. 
demarcated in accordance with a treaty, judicial decision, or arbitral award, or, in the absence of frontiers thus demarcated, invasion affecting a region which is under the effective jurisdiction of another State."

The Organ of Consultation is formed by the Ministers of Foreign Affairs of the republics which have ratified the treaty, but the Governing Board of the Pan-American Union may act provisionally in its place until its meeting is brought about. Its decisions will be taken by a vote of two-thirds of the signatory States. The treaty is to remain in force indefinitely. It may, however, be denounced by any high contracting party by notification to the PanAmerican Union, and ceases to be in force in respect of that State two years after the notification has been received.

Both Argentina and Chile have made it clear that they consider the Antarctic dispute to be covered by the treaty and that Great Britain's conduct in the Falkland Islands Dependencies constitutes an aggression against all the Americas within the meaning of the treaty.

The final published conference documents include "Statements" by Argentina, Chile and the United States, as follows:

\section{Argentina:}

The Argentine Delegation declares that within the waters adjacent to the South American Continent, along the coasts belonging to the Argentine Republic in the Security Zone [Article IV of Treaty], it does not recognize the existence of colonies or possessions of European countries and it adds that it especially reserves and maintains intact the legitimate titles and rights of the Argentine Republic to the Falkland (Malvinas) Islands, the South Georgia Islands, the South Sandwich Islands, and the lands included in the Argentine Antarctic sector, over which the Republic exercises the corresponding sovereignty.

\section{Chile:}

The Delegation of Chile declares that, within the waters adjacent to the South American Continent, in the extension of coast belonging to the Republic of Chile, comprised within the Security Zone, it does not recognize the existence of colonics or possessions of European countries and it adds that it especially reserves and maintains intact the legitimate title and rights of the Republic of Chile to the lands included in the Chilean Antarctic Zone, over which the Republic exercises the corresponding sovereignty.

\section{United States:}

With reference to the reservations made by other Delegations concerning territories located within the region defined in the Treaty, their boundaries, and questions of sovereignty over them, the Delegation of the United States of America wishes to record its position that the Treaty of Rio de Janeiro has no effect upon the sovereignty, national, or international status of any of the territories included in the region defined in Article IV of the Treaty. 